\title{
Effect of piperine and quercetin pretreatment on safety profile of marbofloxacin after repeated oral administration in broiler chickens
}

\author{
Harshad B. Patel*, Urvesh D. Patel, Chirag M. Modi, Dhaval T. Fefar* and Amit R. Bhadaniya* \\ Department of Veterinary Pharmacology and Toxicology, College of Vet. Science and Animal Husbandry, Junagadh Agricultural University, \\ Junagadh-362001, Gujarat, India
}

*Department of Veterinary Pathology, College of Vet. Science and Animal Husbandry, Junagadh Agricultural University, Junagadh-362001, Gujarat, India

\section{Article Info}

Article history

Received 1 September 2020

Revised 21 October 2020

Accepted 24 October 2020

Published online 30 December 2020

Keywords

Marbofloxacin

Piperine

Quercetin

Hemato-biochemical

Histopathological

Broiler chickens

\begin{abstract}
The present study was carried out to investigate the effect of pretreatment of bioenhancers like piperine and quercetin on safety profile of marbofloxacin after repeated oral administration in broiler chickens. Hemato-biochemical and histopathological alterations after repeated dose oral administration of marbofloxacin $(5 \mathrm{mg} / \mathrm{kg}$, PO, 5 days) in normal, piperine, quercetin and both in combination $(10 \mathrm{mg} / \mathrm{kg}$, each, PO, for 3 days) pretreated broiler chickens were investigated. After repeated oral administration of marbofloxacin, mean hemoglobin, packed cell volume, total erythrocyte count and total leukocyte count in quercetin pretreated broiler chickens were $9.52 \pm 0.33 \mathrm{~g} / \mathrm{dl}, 28.33 \pm 1.00 \%, 2.12 \pm 0.05 \times 10^{6} / \mu \mathrm{l}$ and $20.38 \pm 0.29 \times 10^{3} / \mu \mathrm{l}$, respectively which significantly $(p<0.05)$ lower as compared respective values of $12.48 \pm 0.47 \mathrm{~g} / \mathrm{dl}, 35.72 \pm 1.39 \%, 2.80 \pm 0.13 \times 10^{6} / \mu \mathrm{l}$ and $22.81 \pm 0.27 \times 10^{3} / \mu \mathrm{l}$ of control group. However, these alterations were in the normal clinical range of broiler chickens. The differential leukocyte count, mean corpuscular volume, mean corpuscular hemoglobin concentration and mean corpuscular hemoglobin were not significantly different as compared to control group. Biochemical parameters, viz., alanine aminotransferase, aspartate aminotransferase, lactate dehydrogenase, alkaline phosphatase, total protein, creatinine, blood urea nitrogen and total bilirubin were also not significantly different from control group. No major histomorphological changes were observed in liver, intestine and kidney of broiler chickens. The present dosage regimen of piperine, quercetin and marbofloxacin was found to be safe and might be helpful to explore therapeutic efficacy of herbal drugs with antibiotics in broiler chickens.
\end{abstract}

\section{Introduction}

Various bacterial infections like colibacillosis, salmonellosis, pasteurellosis, campylobacterosis, mycoplasmosis, tuberculosis, psittacosis, infectious coryza and coccidiosis are important threats to poultry industry (Hasan et al., 2012). Therapeutic and prophylactic use of antibiotics has improved poultry production to achieve a significant growth (Apata, 2009). Marbofloxacin is a third generation, fluorinated quinolone compound, exclusively developed for use in animals (Brown, 1996). Marbofloxacin inhibits the topoisomerase II (DNA gyrase) and topoisomerase IV enzymes, which are responsible for supercoiling of bacterial DNA (Paradis et al., 2001). Marbofloxacin has shown broad spectrum of antimicrobial activity against gram-negative, some gram-positive bacteria and mycoplasma spp., and used for respiratory, urinary tract and dermatological infections (Spreng et al., 1995; Lefebvre

Corresponding author: Dr. Harshad B. Patel Assistant Professor, Department of Veterinary Pharmacology and Toxicology, College of Veterinary Science and Animal Husbandry, Junagadh Agricultural University, Junagadh-362001, India. E-mail: harshadvet@gmail.com

Tel.: +91-9558514761

Copyright (C) 2020 Ukaaz Publications. All rights reserved.

Email: ukaaz@yahoo.com; Website: www.ukaazpublications.com et al., 1998). Marbofloxacin has shown low bioavailability (56.82\%) after oral administration in chickens (Anadon et al., 2002). Single dose oral administration of marbofloxacin in various animal species and birds also revealed its low oral absorption, which limits its therapeutic effectiveness (Patel et al., 2018).

Therapeutic effective concentration can be achieved with high dose of drug, however, it is associated with the risk of increased toxicity, tissue residues problems and development of antimicrobial resistance (Alhendi et al., 2000). The use of fluoroquinolones must comply with strict withdrawal periods, doses and duration of treatment (Gouvea et al., 2015).

The combination of bioenhancers like piperine, quercetin, genistein, naringin, niazeridine, lysergols, capmul, sinomenine and glycyrrhizin has shown improved bioavailability of various antibiotic drugs (Randhawa et al., 2011). Piperine, an alkaloid present in black pepper (Piper nigrum L.) and long pepper (Piper longum L.) is recognized as the first bioenhancer drug (Atal, 1979). Piperine treatment has shown to increase the oral bioavailability of various fluoroquinolones like ciprofloxacin (Bhise and Pore, 2002), pefloxacin (Madhukar et al., 2008), gatifloxacin (Patel et al., 2011) and marbofloxacin (Chauhan et al., 2020). Quercetin, a flavonoid compound present in various plants and foods including grapes, onions, berries, apples, capers, tea, shallots, and tomatoes having 
important pharmacological effects like antioxidant, antiinflammatory, antihyperlipidemic, anticancerous and antiviral effects (Nijveldt et al., 2001). Quercetin treatment has been reported to increase the bioavailability of moxidectin in sheep (Dupuy et $a l ., 2003)$. Piperine and quercetin both had shown to inhibit CYP3A37 (drug metabolizing enzyme) and MDR1 (P-glycoprotein/ multi drug resistance gene 1) activity in liver and intestine of broiler chickens (Patel et al., 2019).

Therapeutic effective dosage regimen of antibiotics can be determined by investigation of efficacy and safety of drugs. The safety profile of marbofloxacin after repeated administration in cat (Ishak et al., 2008), sheep (Patel et al., 2014) and rat (Chauhan et al., 2017) was reported earlier. However, the safety profile of marbofloxacin after repeated oral administration in piperine and quercetin pretreated broiler chickens have not been evaluated so far. Hence, the present study was planned to investigate the effect of piperine and quercetin pretreatment on hemato-biochemical and histopathological changes after repeated oral administration of marbofloxacin in broiler chickens.

\section{Materials and Methods}

\subsection{Experimental animals}

The experiment was carried out on 30 broiler chickens of strain 'Cobb 400' which were procured from Venky's Pvt. Ltd., Anand, Gujarat. Day-old chicks were reared up to the age of three weeks as per standard CPCSEA guidelines for laboratory animal facility
(CPCSEA, 2003). Broiler starter and finisher feed of BIS (9862-1992) specification (Simran Feeds, Indore, India) and clean wholesome drinking water were provided ad libitum to chickens. Experimental protocol was approved by Institutional Animal Ethics Committee (IAEC), College of Veterinary Science, Junagadh Agricultural University, Junagadh (Protocol No.: JAU/JVC/IAEC/SA/22/2017 dated: 26/05/2017).

\subsection{Drugs and chemicals}

Marbofloxacin tablet $50 \mathrm{mg}$ (Marbomet $^{\mathbb{Q}}$, Intas Pharmaceuticals Limited, Ahmedabad, Gujarat, India) was used for oral administration to broiler chickens. Ready to use analytical kits for estimation of serum enzymes like ALT, AST, LDH and AKP (Greiner Diagnostics, Bahlingen, Germany) and biochemical parameters, viz., total protein, blood urea nitrogen, bilirubin total and creatinine (Diatek Health care Pvt. Ltd., Kolkata, West Bengal, India) were used. Piperine and quercetin for were purchased from Sigma Aldrich, Bangalore, India.

Various active principles from plant origin like piperine, quercetin, curcumin, naringin, rutin, genistein, sinomenin and carvacrol shown to have bioenhancing property. Such agents affect the activities of metabolizing enzymes as well as drug efflux transporters which lead to increase the bioavailability of drug upon simultaneous administration through oral route. Sources, chemical class and mechanism of action of some important bioenhancers are shown in Table 1.

Table 1: Sources, chemical class and mechanism of action of some important bioenhancers

\begin{tabular}{|c|c|c|c|c|}
\hline $\begin{array}{l}\text { Name of } \\
\text { bio-enhancer }\end{array}$ & Plant source & Chemical class & Mechanism of action & References \\
\hline Piperine & Piper longum and Piper nigrum & Alkaloid & $\begin{array}{l}\text { Drug metabolizing enzyme (CYP3A37) inhibition } \\
\text { and drug efflux transporter (MDR-1/P-gp) inhibition }\end{array}$ & $\begin{array}{l}\text { (Atal, 1979; } \\
\text { Patel et al., 2019) }\end{array}$ \\
\hline Quercetin & $\begin{array}{l}\text { Grapes, onions, berries, apples, } \\
\text { capers, tea, shallots and tomatoes }\end{array}$ & Flavonoid & $\begin{array}{l}\text { Drug metabolizing enzyme (CYP3A37) inhibition } \\
\text { and drug efflux transporter (MDR-1/P-gp) inhibition }\end{array}$ & $\begin{array}{l}\text { (Nijveldt et al., 2001; } \\
\text { Patel et al., 2019) }\end{array}$ \\
\hline Curcumin & Curcuma longa & Flavonoid & $\begin{array}{l}\text { Drug metabolizing enzyme (Uridine diphosphate } \\
\text { glucuronyl transferase) inhibition }\end{array}$ & (Basu et al., 2004) \\
\hline Naringin & Grapes, apple, onion and tea & Flavonoid & $\begin{array}{l}\text { Drug metabolizing enzyme (CYP3A4) inhibition } \\
\text { and drug efflux transporter (P-gp) inhibition }\end{array}$ & (Choi and Shin, 2005) \\
\hline Rutin & $\begin{array}{l}\text { Apricots, cherries, grapes, grapefruit, } \\
\text { plums, buckwheat and oranges. }\end{array}$ & Flavonoid & $\begin{array}{l}\text { Inhibition of Breast Cancer Resistance Protein } \\
\text { (BCRP) transporters at intestine }\end{array}$ & (Dogra et al., 2020) \\
\hline Genistein & $\begin{array}{l}\text { Pueraria lobata }(\mathrm{Kudzu}) \text { and } \\
\text { Soybeans }\end{array}$ & Flavonoid & $\begin{array}{l}\text { Drug efflux transporters (ABCB1, BCRP, MRP2) } \\
\text { inhibition and drug metabolism (CYP3A4) inhibition }\end{array}$ & (Li and Choi, 2007) \\
\hline Sinomenine & Sinomenium acutum & Alkloid & Drug efflux transporters $\mathrm{ABCB} 1 / \mathrm{p}$-gp inhibitor & (Chan et al., 2006) \\
\hline Carvacrol & Carum carvi (Caraway) & $\begin{array}{l}\text { Monoterpenoid } \\
\text { phenol }\end{array}$ & $\begin{array}{l}\text { Enhancement of intestine permeation of drug } \\
\text { and inhibition of the P-glycoprotein activity }\end{array}$ & (Choudhary et al., 2014) \\
\hline
\end{tabular}

\subsection{Experimental design}

At the age of 3 weeks, 30 broiler chickens were randomly allocated in to five groups $(n=6)$; group I (control), group II (marbofloxacin $5 \mathrm{mg} / \mathrm{kg}$, PO, 5 days), group III (pretreatment of piperine $10 \mathrm{mg} / \mathrm{kg}$, PO, 3 days + marbofloxacin $5 \mathrm{mg} / \mathrm{kg}$, PO, 5 days), group IV (pretreatment of quercetin $10 \mathrm{mg} / \mathrm{kg}, \mathrm{PO}, 3$ days + marbofloxacin $5 \mathrm{mg} / \mathrm{kg}, \mathrm{PO}, 5$ days) and group V (pretreatment of piperine and quercetin $10 \mathrm{mg} / \mathrm{kg}$, each, PO, for 3 days + marbofloxacin $5 \mathrm{mg} / \mathrm{kg}$, PO, 5 days). Piperine, quercetin and marbofloxacin were administered with oral gavaging bent feeding needle (16 G x 4") as per above treatment schedule daily. Under local anesthesia (lignocaine gel $2.5 \%$ ), blood samples (approx. $2 \mathrm{ml}$ ) were collected at 0 day (before drug administration) and $6^{\text {th }}$ day (after repeated oral administration of marbofloxacin) from jugular vein into sterile 
$\mathrm{K}_{3}$ EDTA and non-heparinized test tubes for hematological and serum biochemical analysis, respectively. Blood samples collected in non-heparinized test tubes were allowed to clot at room temperature. Serum from each sample was collected by centrifugation at 5000 $\mathrm{rpm}$ for $10 \mathrm{~min}$ at $4^{\circ} \mathrm{C}$ (Eppendorf $5430 \mathrm{R}$, Germany) and stored at $-20^{\circ} \mathrm{C}$ for biochemical analysis.

\subsection{Hematological and biochemical parameters evaluation}

Hemoglobin $(\mathrm{Hb})$ estimation was carried out by Sahli's hemoglobinometer and expressed as gram per cent, PCV was estimated by microhematocrit method and expressed as per cent (Coles, 1986). Estimation of TEC, TLC and DLC was carried out as per standard method (Jain, 1986). Serum biochemical parameters were analyzed by using standard kits with automatic biochemistry analyzer (Model: Dia-chem 240 plus, Diatek, China).

\subsection{Histopathological evaluation}

For histopathological examinations, liver, intestine, and kidney were collected in $10 \%$ neutral buffered formalin. The formalin fixed tissues were subjected to paraffin wax embedding for tissue sectioning (5 micron) thickness with semi-automated rotary microtome (Leica Biosystems, Germany) and were stained with haematoxylin and eosin stain (Luna, 1968). The stained slides were viewed under microscope (H \& E stain x 100 and $x$ 400) and histopathological lesions were recorded.

\subsection{Statistical analysis}

The data obtained for hematological and biochemical parameters were presented as Mean \pm SE and differences among the various treatment groups were analyzed by one-way analysis of variance (ANOVA), followed by post hoc Tukey high significant difference test. Where $p \leq 0.05$ was considered as statistically significant (Snedecor and Cochran, 1982).

\section{Results}

\subsection{Hematological and biochemical parameters}

Following repeated dose oral administration of marbofloxacin $(5 \mathrm{mg} / \mathrm{kg}$, PO, for 5 days) in normal, piperine, quercetin alone and both in combination pretreated $(10 \mathrm{mg} / \mathrm{kg}$ each, PO, for 3 days) broiler chickens, the hematological parameters are presented in Table 2 and Figure 1 ; and biochemical parameters are presented in Table 3 and Figure 2.

Table 2: Effect of piperine, quercetin alone and both in combination pretreatment (10 $\mathrm{mg} / \mathrm{kg}$ each, PO, for 3 days $)$ on hematological parameters $($ Mean \pm SE) following repeated dose oral administration of marbofloxacin $(5 \mathrm{mg} / \mathrm{kg}$, PO, for 5 days) in broiler chickens ( $\mathrm{n}=6)$

\begin{tabular}{|c|c|c|c|c|c|}
\hline $\begin{array}{l}\text { Hematological } \\
\text { parameters }\end{array}$ & Control & Marbofloxacin & $\begin{array}{l}\text { Piperine }+ \\
\text { Marbofloxacin }\end{array}$ & $\begin{array}{l}\text { Quercetin + } \\
\text { Marbofloxacin }\end{array}$ & $\begin{array}{l}\text { Piperine }+ \text { Quercetin } \\
+ \text { Marbofloxacin }\end{array}$ \\
\hline HB $(\mathrm{g} / \mathrm{dl})$ & $12.48 \pm 0.47^{b}$ & $10.93 \pm 0.33^{\mathrm{ab}}$ & $11.23 \pm 0.38^{\mathrm{b}}$ & $9.52 \pm 0.33^{\mathrm{a}}$ & $10.95 \pm 0.40^{\mathrm{ab}}$ \\
\hline PCV (\%) & $35.72 \pm 1.39^{b}$ & $31.88 \pm 1.19^{\mathrm{ab}}$ & $32.97 \pm 1.19^{\mathrm{ab}}$ & $28.33 \pm 1.00^{\mathrm{a}}$ & $31.52 \pm 1.22^{\mathrm{ab}}$ \\
\hline TEC $\left(\times 10^{6} / \mu \mathrm{l}\right)$ & $2.80 \pm 0.13^{\mathrm{b}}$ & $2.56 \pm 0.11^{\mathrm{ab}}$ & $2.55 \pm 0.09^{\mathrm{ab}}$ & $2.12 \pm 0.05^{\mathrm{a}}$ & $2.60 \pm 0.24^{\mathrm{ab}}$ \\
\hline TLC $\left(\times 10^{3} / \mu \mathrm{l}\right)$ & $22.81 \pm 0.27^{b}$ & $21.82 \pm 0.14^{\mathrm{b}}$ & $21.88 \pm 0.31^{\mathrm{b}}$ & $20.38 \pm 0.29^{\mathrm{a}}$ & $21.83 \pm 0.46^{\mathrm{b}}$ \\
\hline Heterophils (\%) & $27.17 \pm 2.26^{\mathrm{a}}$ & $29.17 \pm 1.47^{\mathrm{a}}$ & $26.33 \pm 1.12^{\mathrm{a}}$ & $27.67 \pm 1.28^{\mathrm{a}}$ & $27.67 \pm 1.33^{\mathrm{a}}$ \\
\hline Basophils (\%) & $0.33 \pm 0.21^{\mathrm{a}}$ & $0.83 \pm 0.40^{\mathrm{a}}$ & $0.50 \pm 0.22^{\mathrm{a}}$ & $1.17 \pm 0.31^{\mathrm{a}}$ & $0.67 \pm 0.33^{\mathrm{a}}$ \\
\hline Eosinophils (\%) & $2.17 \pm 0.31^{\mathrm{a}}$ & $3.00 \pm 0.58^{\mathrm{a}}$ & $2.67 \pm 0.67^{a}$ & $3.00 \pm 0.73^{a}$ & $2.17 \pm 0.48^{\mathrm{a}}$ \\
\hline Lymphocytes (\%) & $60.67 \pm 2.11^{\mathrm{a}}$ & $57.33 \pm 1.65^{\mathrm{a}}$ & $59.83 \pm 1.35^{\mathrm{a}}$ & $59.33 \pm 1.15^{\mathrm{a}}$ & $59.33 \pm 1.71^{\mathrm{a}}$ \\
\hline Monocytes (\%) & $10.33 \pm 0.76^{\mathrm{a}}$ & $9.67 \pm 0.71^{\mathrm{a}}$ & $10.67 \pm 0.67^{a}$ & $9.33 \pm 0.71^{\mathrm{a}}$ & $10.17 \pm 0.01^{\mathrm{a}}$ \\
\hline $\mathrm{MCV}(\mathrm{fL})$ & $128.13 \pm 2.54^{\mathrm{a}}$ & $124.94 \pm 1.74^{\mathrm{a}}$ & $129.38 \pm 1.85^{\mathrm{a}}$ & $133.13 \pm 2.23^{a}$ & $123.90 \pm 5.52^{\mathrm{a}}$ \\
\hline MCHC (\%) & $34.94 \pm 0.52^{\mathrm{a}}$ & $34.36 \pm 0.64^{\mathrm{a}}$ & $34.11 \pm 0.53^{\mathrm{a}}$ & $33.72 \pm 0.43^{\mathrm{a}}$ & $34.70 \pm 0.50^{\mathrm{a}}$ \\
\hline $\mathrm{MCH}(\mathrm{pg})$ & $44.74 \pm 1.06^{\mathrm{a}}$ & $42.93 \pm 0.95^{\mathrm{a}}$ & $44.09 \pm 0.79^{\mathrm{a}}$ & $44.88 \pm 0.78^{\mathrm{a}}$ & $43.14 \pm 2.18^{\mathrm{a}}$ \\
\hline
\end{tabular}

HB: hemoglobin, PCV: packed cell volume, TEC: total erythrocyte count, TLC: total leukocyte count, MCV: mean corpuscular volume, MCHC: mean corpuscular hemoglobin concentration, MCHC: mean corpuscular hemoglobin. Difference among the various treatment groups were analyzed by one way analysis of variance (ANOVA), followed by Tukey high significant difference test. Values with different superscripts in each row are significantly different $(p<0.05)$.

Table 3: Effect of piperine, quercetin alone and both in combination pretreatment ( $10 \mathrm{mg} / \mathrm{kg}$ each, PO, for 3 days $)$ on biochemical parameters $($ Mean \pm SE) following repeated dose oral administration of marbofloxacin $(5 \mathrm{mg} / \mathrm{kg}$, PO, for 5 days) in broiler chickens ( $\mathrm{n}=6$ )

\begin{tabular}{|c|c|c|c|c|c|}
\hline $\begin{array}{l}\text { Biochemical } \\
\text { parameters }\end{array}$ & Control & Marbofloxacin & $\begin{array}{l}\text { Piperine }+ \\
\text { Marbofloxacin }\end{array}$ & $\begin{array}{l}\text { Quercetin + } \\
\text { Marbofloxacin }\end{array}$ & $\begin{array}{l}\text { Piperine + Quercetin } \\
+ \text { Marbofloxacin }\end{array}$ \\
\hline ALT (IU/L) & $3.75 \pm 0.61^{\mathrm{a}}$ & $3.87 \pm 0.77^{a}$ & $3.86 \pm 0.64^{a}$ & $3.77 \pm 0.68^{\mathrm{a}}$ & $4.29 \pm 1.48^{\mathrm{a}}$ \\
\hline AST (IU/L) & $301.66 \pm 22.44^{\mathrm{a}}$ & $271.94 \pm 22.48^{\mathrm{a}}$ & $282.90 \pm 31.91^{\mathrm{a}}$ & $312.48 \pm 13.18^{\mathrm{a}}$ & $335.38 \pm 60.33^{\mathrm{a}}$ \\
\hline LDH (IU/L) & $1376.70 \pm 212.40^{\mathrm{a}}$ & $1078.80 \pm 174.80^{a}$ & $884.4 \pm 100.60^{\mathrm{a}}$ & $961.40 \pm 138.20^{\mathrm{a}}$ & $1520.70 \pm 306.30^{\mathrm{a}}$ \\
\hline ALP (IU/L) & $183.00 \pm 42.60^{\mathrm{a}}$ & $132.03 \pm 41.38^{\mathrm{a}}$ & $207.52 \pm 46.66^{\mathrm{a}}$ & $129.97 \pm 21.70^{\mathrm{a}}$ & $163.55 \pm 43.49^{\mathrm{a}}$ \\
\hline Total protein $(\mathrm{g} / \mathrm{dL})$ & $3.50 \pm 0.23^{\mathrm{a}}$ & $3.37 \pm 0.25^{\mathrm{a}}$ & $3.22 \pm 0.15^{\mathrm{a}}$ & $3.27 \pm 0.15^{\mathrm{a}}$ & $3.31 \pm 0.24^{\mathrm{a}}$ \\
\hline Creatinine $(\mathrm{mg} / \mathrm{dL})$ & $0.10 \pm 0.04^{\mathrm{a}}$ & $0.42 \pm 0.28^{a}$ & $0.05 \pm 0.02^{\mathrm{a}}$ & $0.15 \pm 0.06^{\mathrm{a}}$ & $0.02 \pm 0.01^{\mathrm{a}}$ \\
\hline BUN (mg/dL) & $1.53 \pm 0.24^{\mathrm{a}}$ & $1.13 \pm 0.26^{\mathrm{a}}$ & $1.16 \pm 0.10^{\mathrm{a}}$ & $1.54 \pm 0.31^{\mathrm{a}}$ & $1.43 \pm 0.18^{\mathrm{a}}$ \\
\hline Bilirubin total $(\mathrm{mg} / \mathrm{dL})$ & $0.32 \pm 0.04^{\mathrm{a}}$ & $0.34 \pm 0.03^{a}$ & $0.26 \pm 0.03^{a}$ & $0.33 \pm 0.03^{\mathrm{a}}$ & $0.32 \pm 0.05^{\mathrm{a}}$ \\
\hline
\end{tabular}

ALT: alanine aminotransferase, AST: aspartate aminotransferase, LDH: lactate dehydrogenase, ALP: alkaline phosphatase, BUN: blood urea nitrogen. Difference among the various treatment groups were analyzed by one way analysis of variance (ANOVA), followed by Tukey high significant difference test. Values with different superscripts in each row are significantly different $(p<0.05)$. 

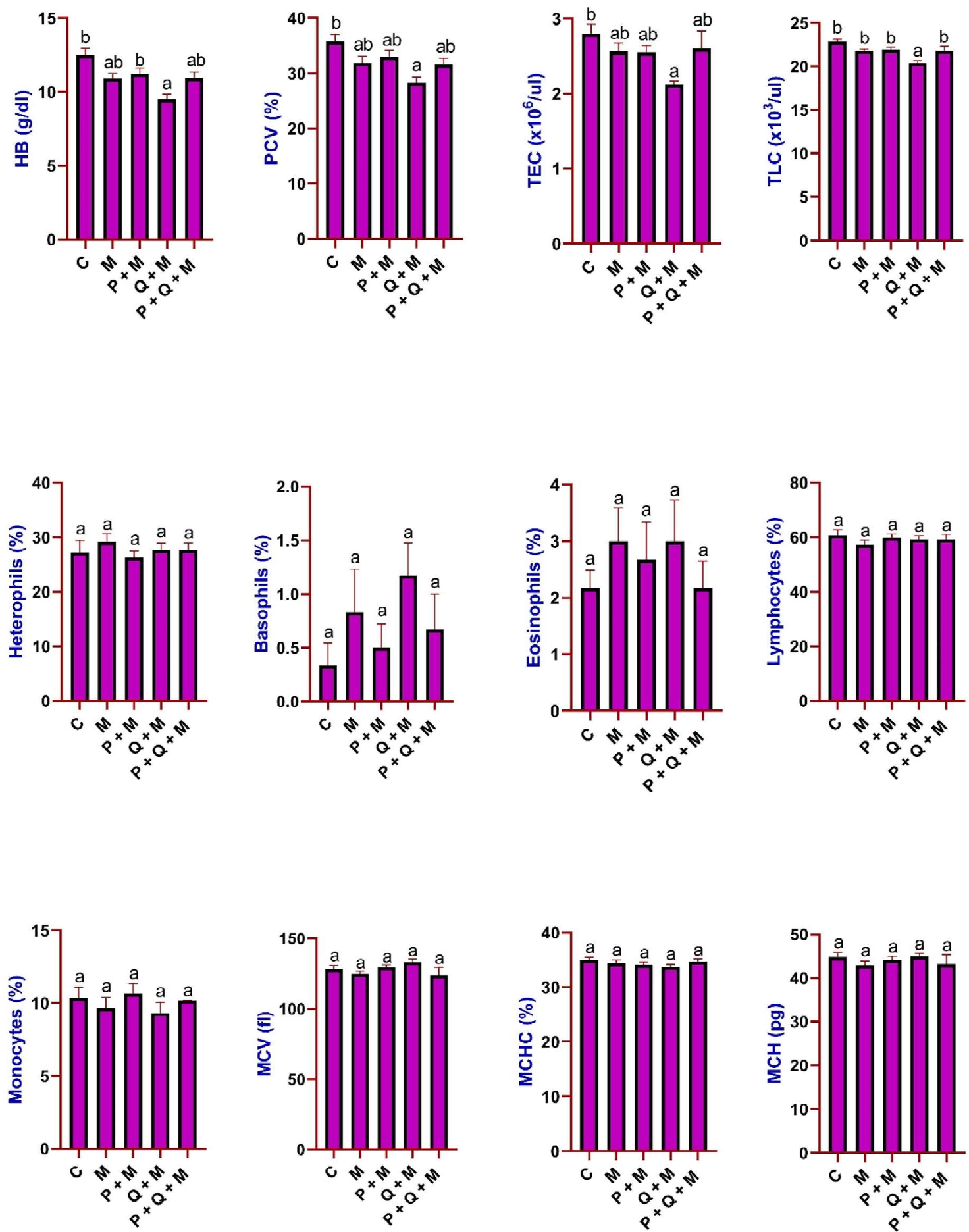

Figure 1: Effect of piperine, quercetin alone and both in combination pretreatment ( $10 \mathrm{mg} / \mathrm{kg}$ each, $\mathrm{PO}$, for 3 days) on hematological parameters (Mean $\pm \mathrm{SE}$ ) following repeated dose oral administration of marbofloxacin $(5 \mathrm{mg} / \mathrm{kg}$, PO, for 5 days) in broiler chickens $(\mathrm{n}=6)$

HB: hemoglobin, PCV: packed cell volume, TEC: total erythrocyte count, TLC: total leukocyte count, MCV: mean corpuscular volume, MCHC: mean corpuscular hemoglobin concentration, MCHC: mean corpuscular hemoglobin. 

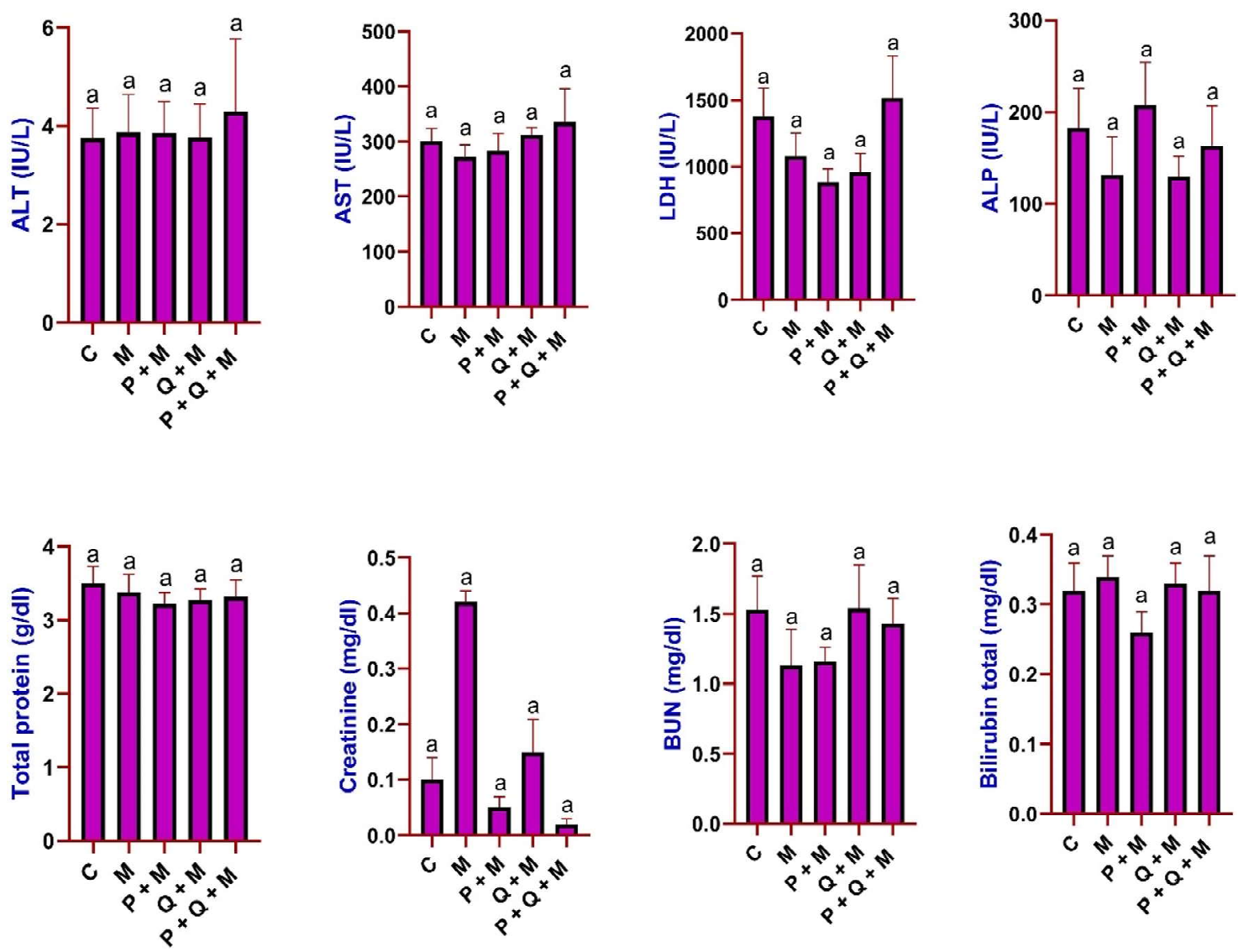

Figure 2: Effect of piperine, quercetin alone and both in combination pretreatment ( $10 \mathrm{mg} / \mathrm{kg}$ each, PO, for 3 days $)$ on biochemical parameters (Mean $\pm \mathrm{SE}$ ) following repeated dose oral administration of marbofloxacin $(5 \mathrm{mg} / \mathrm{kg}$, PO, for 5 days) in broiler chickens $(\mathrm{n}=6)$

ALT: alanine aminotransferase, AST: aspartate aminotransferase, LDH: lactate dehydrogenase, ALP: alkaline phosphatase, BUN: blood urea nitrogen.

After repeated oral administration of marbofloxacin, the mean hemoglobin (HB) concentration in quercetin pretreated broiler chickens was $9.52 \pm 0.33 \mathrm{~g} / \mathrm{dl}$, which significantly $(p<0.05)$ lower than respective values of $12.48 \pm 0.47,10.93 \pm 0.33,11.23 \pm 0.38$ and $10.95 \pm 0.40 \mathrm{~g} / \mathrm{dl}$ in control, marbofloxacin alone, piperine and both in combination pretreated broiler chickens, respectively. Similarly, mean packed cell volume (PCV) in quercetin pretreated broiler chickens was $28.33 \pm 1.00 \%$, which also significantly $(p<0.05)$ lower than respective values of $35.72 \pm 1.39,31.88 \pm$ $1.19,32.97 \pm 1.19$ and $31.52 \pm 1.22 \%$ in control, marbofloxacin alone, piperine and both in combination pretreated broiler chickens, respectively. Total erythrocyte count (TEC) and total leukocyte count (TLC) were also significantly reduced in case of quercetin pretreated group as compared broiler chickens of all other groups. However, these alterations were in the normal clinical range of broiler chickens. Other hematological parameters like heterophils, basophils, eosinophils, lymphocytes, monocytes, MCV, MCHC and $\mathrm{MCH}$ values were not significantly $(p>0.05)$ different among the various treatment groups. The biochemical parameters, viz., ALT,
AST, LDH, ALP, total protein, creatinine, BUN and total bilirubin were also not significantly differ among treatment groups as compared to control group.

\subsection{Histopathological changes in liver, intestine and kidney}

Microscopic view and histopathological changes in liver, intestine and kidney of chickens under different treatments are depicted in Figure 3, Figure 4 and Figure 5, respectively. Upon histopathological examinations, after repeated oral administration of marbofloxacin, mild congestions of liver were observed in all treatment groups as compared control group. No other histopathological changes were observed in central vein, portal vein, bile duct, sinusoids and hepatocytes of liver in all groups. Microscopic examination of intestine revealed normal structure of villi, lamina propria, crypts of lieberkühn (intestinal glands) and goblet cells in all groups. In kidney, mild congestions of renal interstitium were observed in case of quercetin and combination pretreated broiler chickens, whereas other histological structures, viz., renal corpuscle, collecting tubules, bowman's capsule and urinary space were appeared normal in all treatment groups. 


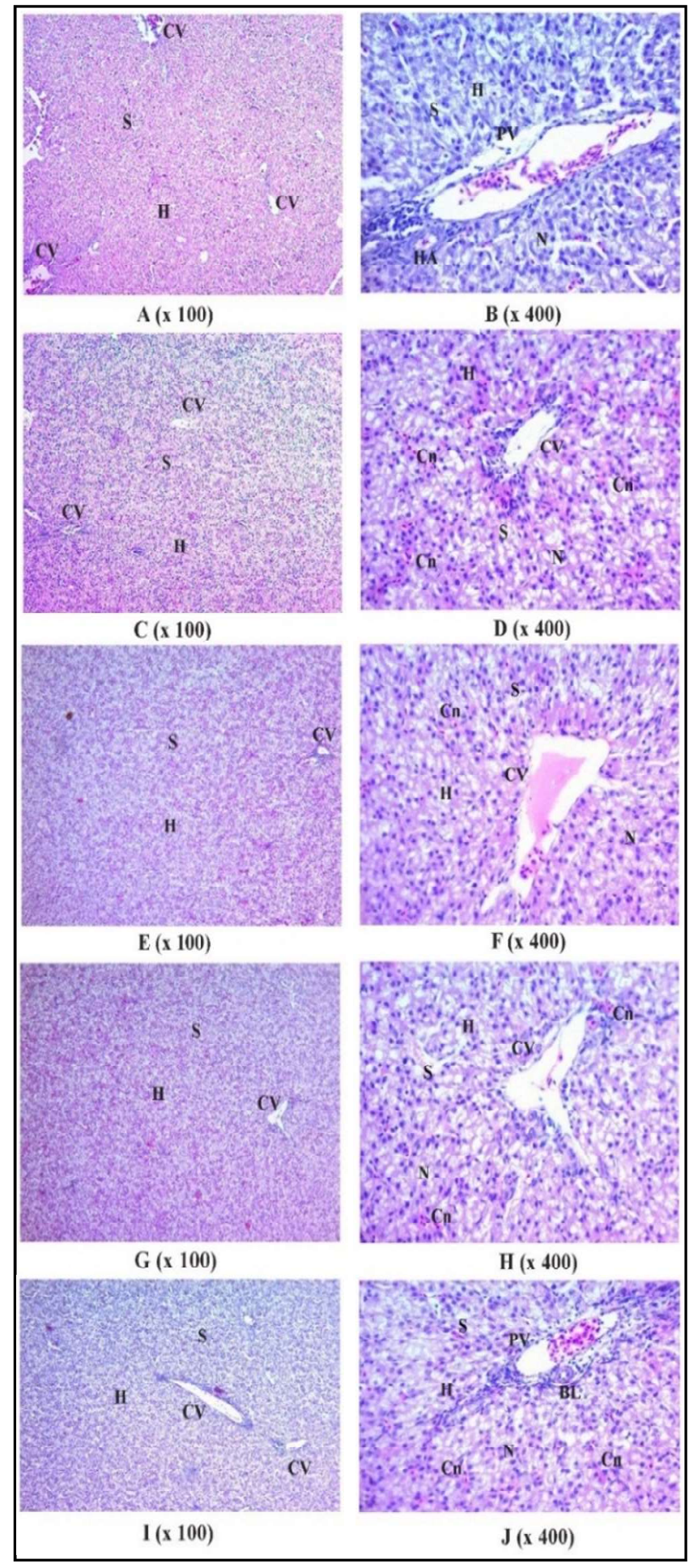

Figure 3: Microscopic view of liver following repeated dose oral administration of marbofloxacin showed normal hepatic lobules and architecture except mild congestions were observed in all treatment groups as compared to control group broiler chickens (H \& E stain x 100, x 400). (A, B): Group I (CON), (C, D): Group II (MAR), (E, F): Group III (PIP + MAR), (G, H): Group IV (QUE + MAR) (I, J): Group V (PIP + QUE + MAR); CV central vein, PV: Portal vein, HA: hepatic artery BL: bile duct, $\mathrm{H}$ : hepatocytes, S: sinusoids, N: nucleus, $\mathrm{Cn}$ : congestion.

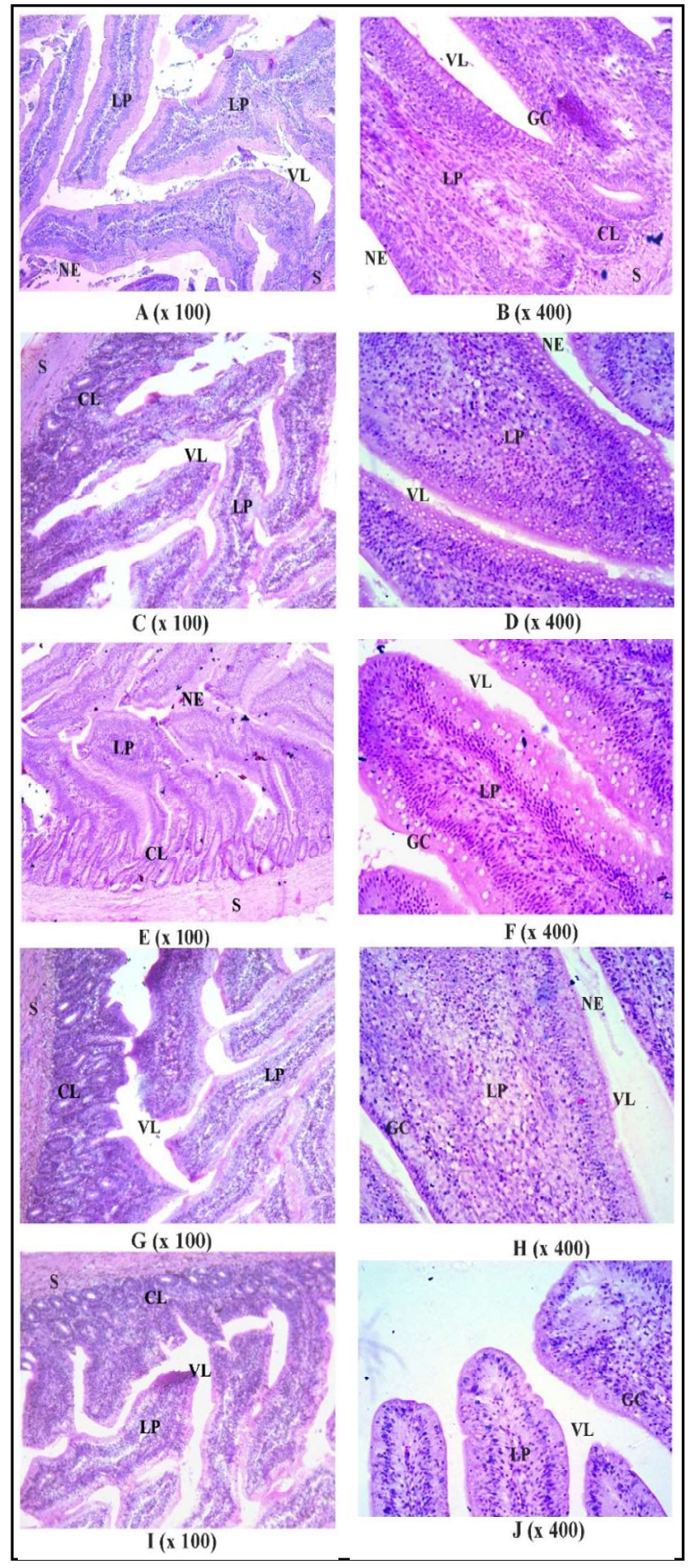

Figure 4: Microscopic view of intestine following repeated dose oral administration of marbofloxacin in different treatment groups showed normal intestinal villi, epithelium, serosa and glands in broiler chickens (H \& E stain x 100, x 400). (A, B): Group I (CON), (C, D): Group II (MAR), (E, F): Group III (PIP + MAR), (G, H): Group IV (QUE + MAR) (I, J): Group V (PIP + QUE + MAR); VL: villi, LP: lamina propria CL: crypts of Lieberkühn, S: serosa, GC: goblet cells, NE: normal epithelium. 


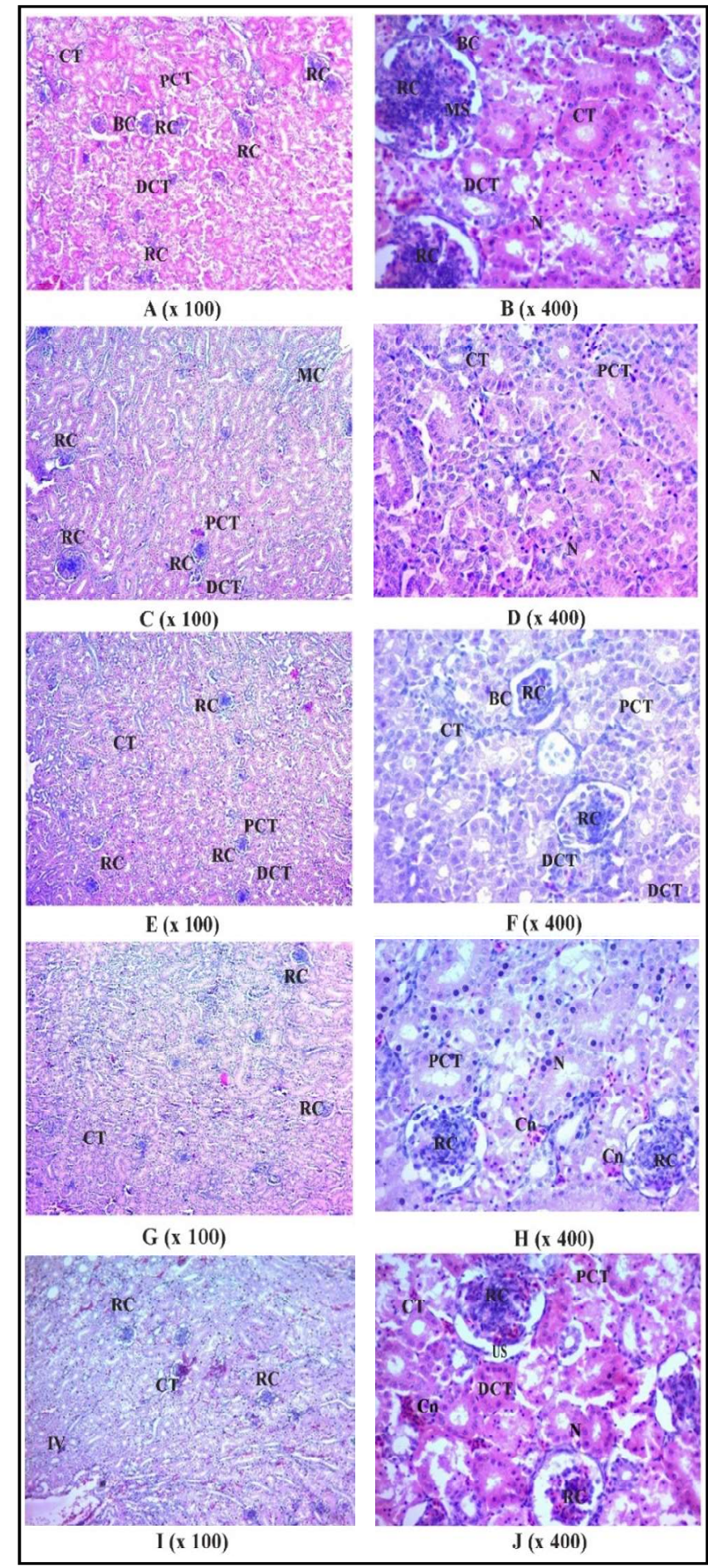

Figure 5: Microscopic view of kidney following repeated dose ora administration of marbofloxacin in different treatmen groups showed normal glomeruli and renal tubular epithelium in broiler chickens (H \& E stain x 100, x 400). (A, B): Group I (CON), (C, D): Group II (MAR), (E, F): Group III (PIP + MAR), (G, H): Group IV (QUE + MAR) (I, J): Group V (PIP + QUE + MAR); $\mathrm{RC}$ : renal corpuscle, $\mathrm{CT}$ : collecting tubules, N: nucleus of podocytes, DCT: distal convoluted tubules, PCT: proximal convoluted tubules, MS: mesangial cells, BC: bowman's capsule, MC: medullary cone, IV: intralobular vein, US: urinary space, $\mathrm{Cn}$ : congestion.

\section{Discussion}

In the present study, to the best of author's knowledge, effects of piperine and quercetin pretreatment on safety profile of marbofloxacin have been studied first time in broiler chickens. After repeated oral administration of marbofloxacin, the mean $\mathrm{HB}, \mathrm{PCV}$, TEC and TLC values were significantly $(p<0.05)$ lower in quercetin pretreated broiler chickens as compared to other groups. However, these alterations were in the normal clinical range of broiler chickens (Hb: 7 - $13 \mathrm{~g} / \mathrm{dl}$; PCV: 22 - $35 \%$; RBC: 2.5 - $3.5 \times 10^{6} / \mu \mathrm{l}$ and WBC: 12 $\left.-30 \times 10^{3} / \mu \mathrm{l}\right)$ as reported by Bounous and Stedman (2000).

Quercetin is a well-known flavonoid compound possesses many important pharmacological activities including bioenhancing effects on co-administered drugs. Nevertheless, quercetin has quite adverse effects on hematopoietic system. Quercetin has iron chelating action and affects iron homeostasis in the body. Non-haem iron is ferric $\left(\mathrm{Fe}^{3+}\right)$ which reduces to ferrous $\left(\mathrm{Fe}^{2+}\right)$ form and influxed into the enterocyte by the action of apical iron transporter (divalent metal transporter-1/DMT1) (Gunshin et al., 1997). Afterwards, ferrous iron is effluxed across the basolateral membrane via the iron exporter (ferroportin/FPN) and enters into systemic circulation (Abboud and Haile, 2000). After single dose of quercetin administration $(50 \mathrm{mg} / \mathrm{kg}$ ), significant down regulation of iron transporters, viz., DMT1 and FPN mRNA levels were observed in duodenum of rats (Lesjak et al., 2014). Authors opine that, due to these possible mechanisms, quercetin pretreatment for three days might have reduced $\mathrm{HB}, \mathrm{PCV}$, TEC and TLC count in broiler chickens. In agreement to our findings, after 28 days of repeated oral quercetin treatment $(20 \mathrm{mg} / \mathrm{kg})$ significant reductions $(p<0.05)$ in $\mathrm{HB}$ (control: $7.34 \pm 0.39 \mathrm{~g} / \mathrm{dl}$; quercetin treated: $5.56 \pm 0.88 \mathrm{~g} / \mathrm{dl}$ ), TEC (control: $4.18 \pm 0.32 \times 10^{6} / \mu \mathrm{l}$; quercetin treated: $\left.2.32 \pm 0.32 \times 10^{6} / \mu \mathrm{l}\right)$ and TLC (control: $7.90 \pm 0.60 \times 10^{3} / \mu \mathrm{l}$; quercetin treated: $6.50 \pm 0.89 \mathrm{x}$ $10^{3} / \mu \mathrm{l}$ ) were observed in rabbits (Parabathina et al., 2011).

In piperine pretreated broiler chickens, no hematological abnormalities were observed in the present study. Similarly, repeated marbofloxacin administration $(5 \mathrm{mg} / \mathrm{kg}$, intramuscular, for 5 days $)$ along with piperine pretreatment $(10 \mathrm{mg} / \mathrm{kg}$, PO, for 5 days) reported being safe and well-tolerated without hematological abnormalities in rats (Chauhan et al., 2017). Cardoso et al. (2012) also did not found significant alterations in HB, PCV, TEC and TLC values of broiler chickens fed with piperine $(60 \mathrm{mg} / \mathrm{kg})$ supplemented diet for 42 days.

The MCV is used to calculate the average size and volume of erythrocyte, the $\mathrm{MCH}$ to measure hemoglobin amount per erythrocyte and the MCHC to know the amount of haemoglobin relative to the size of the cell (Bounous and Stedman, 2000). The normal red blood cell indices of $\mathrm{MCV}, \mathrm{MCH}$ and $\mathrm{MCHC}$ in present study suggests that repeated oral administration of marbofloxacin had no adverse effect on hemoglobin content and size of erythrocytes in broiler chickens. Furthermore, after 21 days of repeated oral administration of marbofloxacin $(2 \mathrm{mg} / \mathrm{kg})$, no significant changes were observed in HB, PCV, TEC, TLC and platelet count in Beagle dogs (Lei et al., 2018). Marbofloxacin treatment $(2.75 \mathrm{mg} / \mathrm{kg}$, PO, daily for 14 days) had shown to improve the hemoglobin and PCV values in Mycoplasma haemofelis infected cats as compared to non-treated (control) infected cats (Ishak et al., 
2008). Similarly, after 28 days of oral exposure of other routinely used fluoroquinolones, viz., enrofloxacin, ciprofloxacin and norfloxacin $(0.25 \mathrm{mg} /$ liter of drinking water) had shown no significant changes in hematological values like TLC, PCV, HB and in TEC in laying hens (Rehman et al., 2019). Earlier researchers also did not observe hematological alterations in HB, PCV, TEC and TLC values after repeated oral administration of gatifloxacin $(10 \mathrm{mg} / \mathrm{kg}$, for 14 days) and gemifloxacin ( $10 \mathrm{mg} / \mathrm{kg}$, for 5 days $)$ in broiler chickens (Devada et al., 2012; Gohel et al., 2018).

During investigation of therapeutic efficacy and safety of target compound, it is essential to evaluate its systemic action on vital body organ performance indexes. In present study, the biochemical parameters, viz., alanine aminotransferase (ALT), aspartate aminotransferase (AST), lactate dehydrogenase (LDH), alkaline phosphatase (ALP), total protein, creatinine, BUN and total bilirubin were not significantly different as compared to control group. Kuttappan et al. (2013) observed that increase in the AST and ALT serum levels indicate liver damage caused by the metabolism of target compound and other feed additives in broiler chickens. Creatinine is a biomarker of kidney function. The kidney plays an important role in excretion of waste products resulting from protein metabolism and muscle contraction. Increased level of serum creatinine indicates compromised kidney functions (Ileke et al., 2014). Protein metabolism, stress and dehydration increase the concentration of blood urea nitrogen in the blood (Chernecky and Berger, 2008).

Normal range of AST, ALT, creatinine and BUN after repeated oral administration of marbofloxacin suggests minimal or no side effects of drug on liver and kidney functions of broiler chickens. In agreement to this, Mahmood (2013) also did not found significant changes in serum biochemical parameters following daily intramuscular administration marbofloxacin $(2 \mathrm{mg} / \mathrm{kg})$ for five days in sheep. Patel et al. (2014) also reported that after intravenous administration of marbofloxacin $(2 \mathrm{mg} / \mathrm{kg})$ no alterations were seen in biochemical parameters in sheep. The mean values of AST, ALT, ALP, LDH, BUN, total protein, albumin, creatinine and total bilirubin were also not significantly altered after repeated oral administration of levofloxacin $(10 \mathrm{mg} / \mathrm{kg}$ ) for 14 days in White Leg Horn layer birds (Patel et al., 2009).

Upon histopathological examinations, after repeated oral administration of marbofloxacin, mild congestions of liver were observed in all treatment groups as compared control group. In agreement to our findings, after repeated oral administration of marbofloxacin $(5 \mathrm{mg} / \mathrm{kg}$ for 5 days) alone and in piperine pretreated ( $10 \mathrm{mg} / \mathrm{kg}$ for 3 days) rats mild degree of congestion of hepatocytes was observed (Chauhan et al., 2019). Microscopic examination of intestine revealed normal structure of villi, lamina propria, crypts of lieberkühn (intestinal glands) and goblet cells in all groups. In kidney, mild congestions of renal interstitium were observed in case of quercetin and combination pretreated broiler chickens. Similar to our findings, after 21 days of repeated oral administration of marbofloxacin $(2 \mathrm{mg} / \mathrm{kg}$ ), no major histopathological abnormalities were found in liver, heart, spleen, lungs and kidneys of Beagle dogs (Lei et al., 2018).

\section{Conclusion}

The piperine alone and piperine and quercetin combined pretreatment had no significant effect on safety profile of marbofloxacin after repeated oral administration in broiler chickens. Quercetin a flavonoid compound had shown to produce reductions in HB, PCV, TEC and TLC values of broiler chickens. However, these hematological alterations were in the normal clinical range of broiler chickens. After repeated oral dose of marbofloxacin, major biochemical and histological alterations were not observed in broiler chickens. Overall, piperine and quercetin pretreatment along with repeated oral administration of marbofloxacin found to be safe and well tolerated in broiler chickens. Findings of present study pave way to design appropriate therapeutic dosage regimens of piperine and quercetin like bioenhancers with marbofloxacin for broiler chickens.

\section{Acknowledgments}

The authors are highly grateful to Junagadh Agricultural University, Junagadh, Gujarat, India for providing funds, research and animal facilities to undertake the research work.

\section{Conflict of interest}

The authors declare that there are no conflicts of interest in the course of conducting the research. All the authors had final decision regarding the manuscript and decision to submit the findings for publication.

\section{References}

Abboud, S. and Haile, D. J. (2000). A novel mammalian iron-regulated protein involved in intracellular iron metabolism. J. Biol. Chem., 275:19906-19912.

Alhendi, A. B.; Homeida, A. M. and Gaili, E. S. (2000). Drug residues in broiler chickens fed with antibiotics in ration. Vet. Arhiv., 70:199-205.

Anadon, A.; Martinez-Larranaga, M. R.; Diaz, M. J.; Martinez, M. A.; Frejo, M. T.; Martinez, M.; Tafur, M. and Castellano, V. J. (2002). Pharmacokinetic characteristics and tissue residues for marbofloxacin and its metabolite N-desmethyl-marbofloxacin in broiler chickens. Am. J. Vet. Res., 63:927-933.

Apata, D. F. (2009). Antibiotic resistance in poultry. Int. J. Poult. Sci., 8:404-408.

Atal, C. K. (1979). A breakthrough in drug bioavailability: A clue from age old wisdom of Ayurveda. IDMA Bull., 10:483-484.

Basu, N. K.; Kole, L.; Kubota, S. and Owens, I.S. (2004). Human udpglucuronosyltransferases show atypical metabolism of mycophenolic acid and inhibition by curcumin. Drug Metab. Dispos., 32:768-773.

Bhise, S. B. and Pore, V. Y. (2002). Influence of co-administration of piperine on pharmacokinetic profile of ciprofloxacin. Indian Drugs, 39:166-168.

Bounous, D. and Stedman, N. (2000). Normal avian hematology: Chicken and turkey. In: Schalm's Veterinary Hematology ( $5^{\text {th }}$ edition) (ed. Feldman, B. F.; Zinkl, J. G. and Jain, N. C.), Lippincott, Williams and Wilkins, Philadelphia, U. S. A., pp:1147-1154.

Brown, S. A. (1996). Fluoroquinolones in animal health. J. Vet. Pharmacol. Ther., 19:1-14. 
Cardoso, V. da. S.; de Lima, C. A. R.; de Lima, M. E. F.; Dorneles, L. E. G. and Danelli, M. G. M. (2012). Piperine as a phytogenic additive in broiler diets. Pesqui. Agropecu. Bras., 47:489-496.

Chan, K.; Liu, Z. Q.; Jiang, Z. H.; Zhou, H.; Wong, Y. F.; Xu, H. X. and Liu, L. (2006) The effects of sinomenine on intestinal absorption of paeoniflorin by the averted rat gut sac model. J. Ethnopharmacol., 103:425-432.

Chauhan, V. B.; Modi, C. M.; Patel, H. B. and Patel, U. D. (2019). Evaluation of pathophysiological alterations in rats administered with marbofloxacin alone and with piperine pretreatment. Ann. Phytomed., 8:178-184.

Chauhan, V. B.; Modi, C. M.; Patel, U. D. and Patel, H. B. (2020). The effect of piperine pre-conditioning on the pharmacokinetics of orally administered marbofloxacin in rats. Vet. Arhiv, 90:69-75.

Chauhan, V. B.; Modi, C. M.; Patel, U. D.; Patel, H. B.; Kalaria, V. A.; Fefar, D. T.; Bhadarka, D. H.; Solanki, S. L. and Ahmed, S. R. (2017). Safety profile of marbofloxacin following repeated intramuscular administration alone and piperine pretreated rats. Ann. Phytomed., 6:88-92.

Chernecky, C. C. and Berger, B. J. (2008). Laboratory tests and diagnostic procedures $\left(5^{\text {th }}\right.$ edition). Saunders Elsevier, St Louis, Philadelphia, U.S.A.

Choi, J. S. and Shin, S. C. (2005). Enhanced paclitaxel bioavailability after oral coadministration of paclitaxel pro-drug with naringin to rats. Int. J. Pharm., 292:149-156.

Choudhary, N.; Khajuria, V.; Gillani, Z. H.; Tandon, V. R. and Arora, E. (2014). Effect of Carum carvi, a herbal bioenhancer on pharmacokinetics of anti-tubercular drugs: A study in healthy human volunteers. Perspect. Clin. Res., 5:80-84.

Coles, H. E. (1986). Veterinary Clinical Pathology ( $4^{\text {th }}$ edition $)$. W.B. Saunders, Philadelphia, U. S. A., pp:17-19.

CPCSEA (2003). Committee for the purpose of control and supervision on experiments on animals. Guidelines for laboratory animal facility. Indian J. Pharmacol., 35:257-274.

Devada, S. S.; Walunj, U. D.; Patil, A. J.; Patel, J. H.; Bhavsar, S. K. and Thaker, A. M. (2012). Safety and tissue residue determination of gatifloxacin in broiler chicken. J. Adv. Vet. Res., 2:9-14.

Dogra, A.; Gour, A.; Bhatt, S.; Sharma, P.; Sharma, A.; Kotwal, P.; Wazir, P.; Mishra P.; Singh, G. and Nandi, U. (2020). Effect of rutin on pharmacokinetic modulation of diclofenac in rats. Xenobiotica, 2:1-9.

Dupuy, J.; Larrieu, G.; Sutra, J. F.; Lespine, A. and Alvinerie, M. (2003). Enhancement of moxidectin bioavailability in lamb by a natural flavonoid: quercetin. Vet. Parasitol., 112:337-347.

Gohel, R. H.; Sadariya, K. A.; Maradiya, J. J. and Thaker, A. M. (2018). Safety evaluation of repeated oral administration of gemifloxacin in broiler birds. Indian J. Vet. Sci. Biotechnol., 13:1-4.

Gouvea, R.; dos Santos, F. F.; de Aquino, M. H. C. and de Pereira, V. L. (2015) Fluoroquinolones in industrial poultry production, bacterial resistance and food residues: a review. Brazilian J. Poult. Sci., 17:1-10.

Gunshin, H.; Mackenzie, B.; Berger, U. V.; Gunshin, Y.; Romero, M. F.; Boron, W. F.; Nussberger, S.; Gollan, J. L. and Hediger, M. A. (1997). Cloning and characterization of a mammalian proton-coupled metal-ion transporter. Nature, 388:482-488.

Hasan, R. A.; Ali, M. H.; Siddique, M. P.; Rahman, M. M. and Islam, M. A. (2012) Clinical and laboratory diagnoses of common bacterial diseases of broiler and layer chickens. Bangladesh J. Vet. Med., 8:107-115.
Ileke K. D.; Odeyemi, O. O. and Ashamo, M. O. (2014). Toxicological and histopathological effects of cheese wood, Alstonia boonei de wild stem bark powder used as cowpea protectant against cowpea bruchid, Callosobruchus maculatu (fab.) [Coleoptera: Chrysomelidae] on albino rats. Int. J. Mol. Med., 4:23-33.

Ishak, A. M.; Dowers, K. L.; Cavanaugh, M. T.; Powell, C. C.; Hawley, J. R.; Radecki, S. V. and Lappin, M. R. (2008). Marbofloxacin for the treatment of experimentally induced Mycoplasma haemofelis infection in cats. J. Vet. Intern. Med., 22:288-292.

Jain, N. C. (1986). Schalm's Veterinary Hematology (4 $4^{\text {th }}$ edition). Lea and febiger, Philadelphia, U. S. A., pp:120-138.

Kuttappan, V. A.; Huff, G. R.; Huff, W. E.; Hargis, B. M.; Apple, J. K.; Coon, C. and Owens, C. M. (2013). Comparison of hematologic and serologic profiles of broiler birds with normal and severe degrees of white striping in breast fillets. Poult. Sci., 92:339-345.

Lefebvre, H. P.; Schneider, M.; Dupouy, V.; Laroute, V.; Costes, G.; Delesalle, L. and Toutain, P. L. (1998). Effect of experimental renal impairment on disposition of marbofloxacin and its metabolites in the dog. J. Vet. Pharmacol. Ther., 21:453-461.

Lei, Z.; Liu, Q.; Yang, B.; Khaliq, H.; Ahmed, S.; Fan, B.; Cao, J. and He, Q. (2018). Evaluation of marbofloxacin in Beagle dogs after oral dosing: preclinical safety evaluation and comparative pharmacokinetics of two different tablets. Front. Pharmacol., 9:1-12.

Lesjak, M.; Hoque, R.; Balesaria, S.; Skinner, V.; Debnam, E. S.; Srai, S. K. S. and Sharp, P. A. (2014). Quercetin inhibits intestinal iron absorption and ferroportin transporter expression in vivo and in vitro. PLoS One. 9:e102900.

Li, X. and Choi, J. S. (2007). Effect of genistein on the pharmacokinetics of paclitaxel administered orally or intravenously in rats. Int. J. Pharm., 337:188-193.

Luna, L. G. (1968). Routine staining procedures. Hematoxylin and eosin stains. Manual of histologic staining methods of the Armed Forces Institute of Pathology ( $3^{\text {rd }}$ edition). McGraw-Hill, New York, U. S. A., pp:32-39.

Madhukar, S. D.; Varshneya, C.; Dardi, M. S. and Katoch, V. C. (2008). Effect of trikatu pretreatment on the pharmacokinetics of pefloxacin administered orally in mountain Gaddi goats. J. Vet. Sci., 9:25-29.

Mahmood, A. H. (2013). Pharmacokinetics, pharmacodynamics and safety of marbofloxacin and trovafloxacin in Sheep. PhD Thesis, The University of Queensland, Brisbane, Australia.

Nijveldt, R. J.; Nood, E. V.; van Hoorn, D. E.; Boelens, P. G.; Norren, K.; van Leeuwen, P. A. (2001). Flavonoids: A review of probable mechanisms of action and potential applications. Am. J. Clin. Nutr., 74:418-25.

Parabathina, R. K.; Muralinath, E.; Lakshmana Swamy, P.; Hari Krishna, V. V. S. N. and Shanthi Sree, K. (2011). Effects of vitamin-E, morin, rutin, quercetin against doxorubicin in rabbits: A haematological study. Res. J. Pharm. Biol. Chem. Sci., 2:74-84.

Paradis, M.; Abbey, L.; Baker, B.; Coyne, M.; Hannigan, M.; Joffe, D.; Pukay, B.; Trettien, A.; Waisglass, S. and Wellington, J. (2001). Evaluation of the clinical efficacy of marbofloxacin (Zeniquin) tablets for the treatment of canine pyoderma: an open clinical trial. Vet. Dermatol., 12:163-169.

Patel, H. B.; Mody, S. K.; Singh, R. D.; Raval, S. H. and Patel, H. A. (2014). Hematology and plasma biochemistry influenced by administration of marbofloxacin in Sheep: Safety impact. J. Vet. Pharmacol. Toxicol., 13:156-160. 
Patel, H. B.; Patel, U. D.; Mathapati, B. S. and Modi, C. M. (2019). Effect of piperine and quercetin alone or in combination with marbofloxacin on CYP3A37 and MDR1 mRNA expression levels in broiler chickens. Res. Vet. Sci., 126:178-183.

Patel, H. B.; Patel, U. D.; Modi, C. M.; Ahmed, S. and Solanki S. L. (2018), Pharmacokinetic profiles of marbofloxacin following single and repeated oral administration in broiler chickens. Ann. Phytomed., 7:174-179.

Patel, J. H.; Varia, R. D.; Patel, U. D.; Vihol, P. D.; Bhavsar, S. K. and Thaker, A. M. (2009). Safety level of levofloxacin following repeated oral administration in WLH layer birds. Vet. World, 2:137-139.

Patel, S.; Devada, S.; Patel, H.; Patel, N.; Bhavsar, S. and Thaker, A. (2011). Influence of co-administration of piperine on pharmacokinetic profile of gatifloxacin in layer birds. Glob. Vet., 7:427-432.
Randhawa, G. K.; Kullar, J. S. and Rajkumar. (2011). Bioenhancer from mothernature and their applicability to modern medicines. Int. J. Appl. Basic Med. Res., 1:5-10.

Rehman, A. U.; Khan, A.; Khan, S.; Maris, H. and Khan, N. (2019). Effect of quinolones on blood glucose level and blood profile of laying hens. J. Anim. Health Prod., 7:51-57.

Snedecor, G. W. and Cochran, W. G. (1982). Statistical Methods ( $\left(8^{\text {th }}\right.$ edition). Iowa State University Press, Ames, Iowa, USA.

Spreng, M.; Deleforge, J.; Thomas, V.; Boisramé, B. and Drugeon, H. (1995). Antibacterial activity of marbofloxacin, a new fluoroquinolone for veterinary use against canine and feline isolates. J. Vet. Pharmacol. Ther., 18:284-289.

Citation Harshad B. Patel, Urvesh D. Patel, Chirag M. Modi, Dhaval T. Fefar and Amit R. Bhadaniya (2020). Effect of piperine and quercetin pretreatment on safety profile of marbofloxacin after repeated oral administration in broiler chickens. Ann. Phytomed., 9(2):283-292. http://dx.doi.org/10.21276/ap.2020.9.2.28 